\title{
The Uniqueness of the Christian-Jewish Dialogue: A Yes and a No
}

\author{
JOHN PAWLIKOWSKI \\ jtmp@ctu.edu \\ Catholic Theological Union, Chicago, IL 60615
}

This article was generated from the February 2016 Saint Joseph's University "Consultation on the Newest Statements about the Christian-Jewish Relationship."

\section{Introduction: "Uniqueness" in the Holy See's 2015 Statement}

The second section of the document released on December 10, 2015 by the Holy See's Commission for Religious Relations with the Jews (part of the Pontifical Council for Ecumenism) titled " 'The Gifts and the Calling of God are Irrevocable' (Rom 11:29): A Reflection on Theological Questions Pertaining to Catholic-Jewish Relations on the Occasion of the $50^{\text {th }}$ Anniversary of Nostra Aetate (No. 4)" (hereafter, G\&C) focuses on the special theological status of the Jewish-Catholic dialogue within the wider context of the interreligious dialogue as a whole. The claim has been around for some time, especially in Catholic Christian circles. It has been posited both by Pope John Paul II's ${ }^{1}$ (and indirectly by Pope Benedict $\mathrm{XVI}^{2}$ who at the beginning of his pontificate reaffirmed John Paul II's views on the church's relationship with Jews and Judaism as his own) and Cardinal Walter Kasper ${ }^{3}$ during his tenure as President of the Holy See's Commission for Religious Relations with the Jews. Such a claim by Catholic leaders raises a twofold question: is the claim accurate and does it marginalize the Christian-Jewish dialogue in an increasingly global church. Put another way does it render Christian-Jewish relations an exclusively "North Atlantic" concern as some have termed it at a time when Christianity is growing in Africa and Asia and showing significant decline in the West. These are issues I will address in the following pages.

G\&C boldly states its claim of uniqueness for the Christian-Jewish relations is the opening sentences of section \#2. Despite considerable conflict between the church and the Jewish People over many centuries the church proudly acknowl-

\footnotetext{
${ }^{1}$ Cf. Eugene J. Fisher and Leon Klenicki, eds., Spiritual Pilgrimage: Texts on Jews and Judaism 1979-1995. Pope John Paul II. (NY: Crossroad and ADL, 1995).

${ }^{2}$ Pope Benedict XVI "Pope Benedict's Speech in Rome Synagogue," (Holy See Press Office, January 17, 2010).

3 Cardinal Walter Kasper, "The Good Olive Tree," America, 185:7 (September 17, 2010); "Christians, Jews, and the Thorny Question of Mission," Origins 32:28, (December 19, 2004 ): 464.
} 
edges its continuing Jewish roots and its enduring continuity with the Jewish People. Hence the church never treats Judaism as just another non-Christian religion. Jews continue to be seen within Christianity as our "elder brothers," our "fathers in faith." G\&C goes on to emphasize the strong positive influence of Jewish teachings and ritual practices on Jesus, his disciples and the early church. It also accepts the developing perspective among contemporary scholarship sometimes referred to as the "Parting of the Ways" research which sees the separation of Judaism and Christianity as a slow process developing over several centuries rather than something that transpired during Jesus' own lifetime or shortly thereafter. ${ }^{4}$

$\mathrm{G} \& \mathrm{C}$ is quite correct in its insistence on the unique aspects of the ChristianJewish relationship in comparison with the dialogues the church maintains with other non-Christian Religious communities. To fully comprehend the teachings of Jesus in the New Testament it is absolutely necessary to place them within the Jewish context of the first century. Not to do so frequently distorts Jesus' perspectives. Amy-Jill Levine has shown how this has often happened in the case of Jesus' parables, often leading to an interpretation of these texts as anti-Judaic. ${ }^{5}$

There is little doubt that the scholarship on the first several centuries of the Jewish-Christian relationship over the past several decades, including the very significant new scholarship regarding the Apostle Paul's outlook on Judaism, ${ }^{6}$ has significantly altered Christianity's self-identity as well as our understanding of the origins and development of the church. As a result, our understanding of the Christian-Jewish relationship has been profoundly altered by the scholarship of the last several decades, an alteration which has left a permanent impact on how the church defines itself today. Such a re-definition of fundamental ecclesial identity needs to be carried over into any dialogues we develop with the Jewish community, as well as other religious communities.

This realization of the church's redefinition in light of the dialogue with Judaism and the new scholarship this dialogue has generated leads me to restate a basic point I emphasized in a recent plenary address on the implications of chapter four of Nostra Aetate for an Asian context given at a conference in Hong Kong. In that presentation I asked the question whether chapter four of Nostra Aetate which deals with the relations with Jews and Judaism carries any relevance for the Church in Asia where dialogue is hardly possible with Jews because of he almost total absence of the Jewish community on that continent. My answer was that indeed chapter four has relevance everywhere because it raises issues of basic Christian identity, especially with regard to Christology and ecclesiology. Hence

\footnotetext{
${ }^{4}$ For a sampling of the "Parting of the Ways" scholarship, see Adam H. Becker and Annette Yoshiro Reeds, eds., The Ways that Never Parted: Jews and Christians in Late Antiquity and the Early Middle Ages. (Tubingen: Mohr Siebeck, 2003).

5 Amy-Jill Levine, Short Stories by Jesus: The Enigmatic Parables of a Controversial Rabbi. (NY: Harper One, 2014).

${ }^{6}$ For a sampling of the new scholarship on Paul, cf. Reimund Bieringer and Didier Pollefeyt, eds., "Paul and Judaism: Crosscurrents in Pauline Exegesis and the Study of Jewish-Christian Relations." (London: T\&T Clark, 2012).
} 
the perspectives emerging from this dialogue need to be brought into discussion between Christians and other non-Christian faith communities. Christian-Jewish dialogue according to $\mathrm{G} \& \mathrm{C}$ can be called "interreligious dialogue" in an analogical way. G\&C argues that the two religious communities are so intrinsically linked that they cannot be regarded as totally distinct religious traditions. I have to say that I have found almost no Jewish religious leader and/or scholar who are willing to embrace such a view. One problem here is certainly the almost total reliance on interpreting Judaism as exclusively a biblical religion on the part of many Christians. This is one of the most frequent criticisms of Christian documents on the relationship with Judaism in Jewish scholarly circles. Judaism should not be equated with biblical Israel, despite the importance of the biblical texts for Jews. Judaism today is also deeply rooted in the post-biblical rabbinic commentaries.

Without question there is a special linkage between Judaism and Christianity that I not present in the relationship between Christianity and other faith traditions. The closest other link is with Islam, but it is quite different from that with Judaism, especially on the theological level. Hence I certainly applaud the Vatican document for is stress on this reality in section two.

But I believe it is necessary to critique G\&C for an overly exclusive approach to the Christian-Jewish relationship. This has the effect of isolating Christian-Jewish relations from any positive impact on other interreligious dialogues and tends to reduce their impact to the North Atlantic region. A number of prominent Catholic scholars working in the wider interreligious dialogue, such as John Borelli, formerly of the United States Conference of Catholic Bishops and now at Georgetown University, have expressed discomfort with the effort evident in $\mathrm{G} \& \mathrm{C}$ to separate the Christian-Jewish dialogue from the remainder of the interreligious scene. The end result of this separation has been o see Judaism frequently omitted from programming on interreligious relations. If such a hard line is maintained by proponents of Catholic-Jewish dialogue it will lead to further marginalization of the Christian-Jewish dialogue at a time when the church is becoming more and more global. In my view such marginalization will prevent the Christian-Jewish dialogue from playing a constructive role in the wider interreligious dialogue.

\section{Integration of Christian-Jewish Dialogue into the Wider Interreligious Dialogue}

In recent years I have begun to argue that new developments in understanding the Jewish context in which the Christian church arose, developments which affect Christian self-understanding need to be integrated into dialogues with Islam, Hinduism, Buddhism, and other religious traditions. We cannot present Christianity in such discussions as though the Christian-Jewish discussion has had no effect on how we perceive Christian origins today. While Christianity is never going to retreat to the status of a Jewish sect we must bring to the wider interreligious dialogue a deeper understanding of how the repositioning of early 
Christianity within a Jewish setting has altered our sense of the church's emergence from the Judaism of the first century. It may be that, as John Borelli has suggested to me in a personal exchange, we should drop the term "unique" with regard to the Christian-Jewish relationship and replace it with the term "distinctive."7

The new emphasis on the church's gradual emergence from Judaism over a period of several centuries I becoming the dominant scholarly view, thanks largely to what has been termed "The Parting of the Ways" research. Christians, whether in the West or in Asia or Africa, can no longer simplistically argue that Jesus established a totally new religious entity, apart from Judaism, during his own lifetime. Increasing scholarly evidence undercuts such an ecclesiological outlook. Some Christian biblical scholars such as John Meier now doubt that Jesus had any intention of establishing an ecclesial community totally separated from Judaism. According to Meier, Jesus showed no interest in creating even a separatist sect or a holy remnant along the lines of the Qumran community. But he did envision the development of a special religious community within Israel. The idea that this community "within Israel would slowly undergo process of separation from Israel as it pursued a mission to the Gentiles in this present world - the long term effect being that his community would become predominantly Gentile itself-finds no lace n Jesus' message or practice."8 Such scholarship, generated to a significant extent by chapter four of Nostra Aetate, needs to be incorporated throughout global Christianity in any statement of ecclesiology. This is another example of how Nostra Aetate's section on Jews and Judaism remains in every interreligious dialogue in which the church is involved.

What I have just underscored about interpretation of the Christian message in terms of its original Jewish base becomes crucial for any dialogical encounters. In dialogues with representatives of the Asian religions Christian participants need to present their tradition in light of the revised perspectives on Christology and ecclesiology that have emerged from the scholarship generated as a result of chapter four of Nostra Aetate. ${ }^{9}$ While G\&C does acknowledge the impact of first century Judaism on the teachings of Jesus and the initial Christian communities it does not draw out the full implications of that influence for Christian self-identity today. And the separation of chapter four from chapters one to three in the Vatican's ongoing implementation of Nostra Aetate remains an obstacle to the

\footnotetext{
7 John Borelli proposed the term "distinctive" rather than "unique" in personal correspondence in June 2016.

${ }^{8}$ John P. Meier, A Marginal Jew: Rethinking the Historical Jesus, Volume 3, "Companions and Competitors." (NY: Doubleday, 2001), 251.

${ }^{9}$ Important works that reflect the spirit of Nostra Aetate include Anthony J. Saldarini, "Jews and Christians in the First Two Centuries: The Changing Paradigm," in Shofar 10 (1992): 32-43; Matt Jackson-McCabe, ed., Jewish Christianity Reconsidered: Rethinking Ancient Groups and Texts (Minneapolis, MN: Augsburg/Fortress Press, 2007); Dabian Udoh, ed., Redefining First Century Jewish and Christian Identities: Essays in Honor of Parish Sanders. (Notre Dame, IN: University of Notre Dame Press, 2008); Hershel Shanks, ed., Partings: How Judaism and Christianity Became Two. (Washington, DC: Biblical Archeology Society, 2013); and Zev Garber, ed., Teaching the Historical Jesus: Issues and Exegesis (London: Routledge, 2015).
} 
integration of the church's newly reappropriation of its original Jewish roots into the dialogues with other religious communities.

So-called "Parting of the Ways" scholarship also affects how we present Jesus' own identity and his ministerial objectives and how and when the church took over responsibility for promulgating his message, a process that developed gradually over several centuries. Buddhists, Jains, Hindus, Muslims and other religious communities that have chosen to engage in dialogue with Christians must come to understand Christianity through this new lens. Only in this way can religious traditions outside of Christianity understand its origins and evolution as we have come to perceive Christian identity today in light of recent scholarship on the Jewish roots of the Church. Thus the Christian-Jewish dialogue to which chapter four gave birth remains pivotal outside the North Atlantic region even where an actual Jewish presence may be negligible or non-existent.

Thus the Christian-Jewish dialogue cannot be isolated from the wider interreligious context. And if we are to be successful in integrating it into dialogues outside the North Atlantic area then we must modify overstated claims about its uniqueness. Christian-Jewish dialogue should be included under the generic umbrella of "interreligious dialogue" while continuing to affirm its important distinctive features. No Jewish leader I know would define Jewish identity as centrally rooted in a bond with Christianity. Christians who make such a claim about the Jewish-Christian relationship do so largely because, as I have said earlier, they overemphasize Judaism as a biblical religion and give insufficient attention to the central role of post-biblical commentaries and such experiences as the Shoah and the re-establishment of the state of Israel in the foraging of contemporary Jewish identities. Without question there are definitely distinctive aspects in the Christian-Jewish encounter that have no parallels in other interreligious dialogues. Christians do share a part of the bible with the Jewish community even though we have often interpreted our common biblical texts in quite different ways. And we regard Jews as having authentic revelation from the Christian theological perspective, as Cardinal Walter Kasper has stressed, ${ }^{10}$ something Christians do not admit with regard to any other interreligious relationship. And as I have stressed above a realistic understanding of the Christian theological outlook is quite dependent on locating it within its original Jewish matrix. All of this does indicate a certain specialness for Christian-Jewish dialogue.

Nonetheless by overstressing these distinctive aspects of the Christian-Jewish dialogue in comparison with other interreligious encounters we run the risk of giving the discussion with Jews and Judaism a measure of superiority, of special privilege, which as the effect of downplaying other dialogues, leaving the impression that they are of secondary importance. But in fact in many parts of the world some of the other interreligious encounters in which the church is involved matter far more on the ground. Here Wesley Ariarajah has made this point, ${ }^{11}$

\footnotetext{
${ }^{10} \mathrm{Cf}$. note 3 .

${ }^{11}$ Wesley Ariarajah, "Towards a Fourth Phase in Christian-Jewish Relations: An Asian Perspective," unpublished paper, Conference on Christian-Jewish Dialogue, Temple Emanu-El, New York, co-
} 
which I think is partially valid, although I would insist that even in BuddhistChristian dialogue the rootedness of the church in Judaism needs to be maintained. This is something that Ariarajah seems unwilling to acknowledge. And from my experience in some encounters coordinated by the World Council of Churches, he is not alone in this outlook.

The "superiority mindset" sometimes found in Christian-Jewish dialogue and evident to a degree in G\&C does little to counteract the views of scholars such as Ariarajah. In fact, it tends to harden their position. The result can be the development of a rather negative attitude towards the importance of the Christian-Jewish encounter and accounts in part for the frequent exclusion of the Christian-Jewish dialogue from conferences dealing with interreligious relations.

It should be noted that there is in fact one sentence in $\mathrm{G} \& \mathrm{C}$ on chapter four of Nostra Aetate which does posit a connection between the Christian-Jewish dialogue and the wider interreligious scene: "The relationship with Judaism can in that sense be seen as a catalyst for the determination of the relationship with the other world religions" (§ 19). Unfortunately this statement receives no further explication and is rather overwhelmed by the strong emphasis on the absolute uniqueness of the Christian-Jewish encounter.

\section{A Positive Effort at Integration}

One scholar of Asian background who has attempted to bring together the two sections (the first three chapters dealing with interreligious understanding and chapter four on Jews and Judaism) of Nostra Aetate is Peter Phan. While the primary orientation of his scholarly work has been the church's dialogues with Asian religions, in which he remains a central figure, he has also been directly involved in Christian-Jewish dialogue as a former member of the ecumenical Christian Scholars Group on Christian-Jewish relations. He has also occasionally written in this area. ${ }^{12}$

With regard to the first three chapters of Nostra Aetate, Phan is quite clear in rejecting any excessively negative notions about religions other than Christianity. Each, according to Phan's reading, plays a singular constructive role in the process of ultimate salvation for humanity and all of creation. He writes as follows:

Religious plurality, then, is not just a matter of fact but also a matter of principle. That is, Judaism and other non-Christian religions should be seen as part of the plan of divine providence and endowed with a particular role in

sponsored by the Center for Interreligious Understanding and the Office of Interreligious Affairs of the World Council of Churches, Nov. 2003.

${ }^{12}$ Peter Phan, "Jews and Judaism in Asian Theology; Historical and Theological Perspectives," Gregorianum 86 (2005): 806-836; "Jesus as the Universal Savior in the Light of God's Eternal Covenant with the Jewish People: A Roman Catholic Perspective," in Mary C. Boys, ed., Seeing Judaism Anew: Christianity's Sacred Obligation. (Lanham, MD: Rowman \& Littlefield, 2005), 127-137. For Phan's overall perspective on interreligious relations, see Peter C. Phan, Being Religious Interreligiously: Asian Perspectives on Interfaith Dialogue, (Maryknoll, NY: Orbis, 2004). 
the history of salvation. They are not merely a "preparation" for, "stepping stones" towards, or "seeds" of Christianity and thus destined to be "fulfilled" by it. Rather, they have their own autonomy and their proper role as ways of salvation, at least for their adherents."13

Turning to Judaism Phan strongly asserts that the Christian understanding of Judaism must begin with an unambiguous and explicit rejection of any claim that the coming of Christ abrogated Judaism. Judaism, in light of Nostra Aetate, must be seen as having continuing vibrancy. It continues to complement Christianity in consort with other religious traditions. While Phan certainly recognizes a special dimension to the Christian-Jewish relationship he does not view this relationship as totally unique. For him the church's relationship with Judaism and the Jewish People is part of the wider complementary role played by the global religious family with regard to Christianity. So I suspect he would remain rather critical of any attempt to isolate Judaism from the wider interreligious scene. The challenge for Christianity in all of its interreligious encounter is how to maintain the validity of the faith perspectives of other religious communities while continuing its traditional belief that human salvation inevitably runs Jesus Christ. Maintaining this twofold perspective becomes especially challenging with regard to Judaism. Many Christological visions have viewed the Christ Event as the termination of Judaism's authentic mandate.

While some ambiguity remains in the way Phan has tried to resolve this tension regarding Judaism's status post-Easter and whether that status is unique in contrast to other religious traditions and faith communities, he basically argues for complementariness between Christianity and Judaism and the other world religions. Awareness of this complementariness through which non-Christian religions can positively impact Christian faith understanding constitutes one of the major benefits of interreligious dialogue. Because Judaism and the other religious traditions add to Christian self-understanding they should never be seen as serving merely as a "preparation" for eventual "fulfillment" by Christianity. These other religions maintain their autonomy in the overall religious sphere. Phan puts his position this way:

There is then a reciprocal relationship between Christianity and Judaism and the other religions. Not only does Christianity complement the non-Christian religions, but also the other religions complement Christianity. In other words, the process of complementarity, enrichment, and even correction is two-way, or reciprocal. This reciprocity in no way endangers the Christian confession that the church has received from Christ the fullness of revelation, since it is one thing to receive the definitive gift of God's self-revelation in Jesus, and quite another to understand it fully and live it completely. Indeed, it is only in a sincere and humble dialogue with other religions that Christianity can come to a fuller realization of its own identity and mission and a

\footnotetext{
${ }^{13}$ Peter Phan, “Jesus as Universal Savior,” 133.
} 
better understanding of the constitutive revelation that it has received from Christ. $^{14}$

Phan then turns to the key phrase in the 2001 document from the Pontifical Biblical Commission titled "The Jewish People and their Sacred Scripture in the Christian Bible." In Part 1:21, the document asserts that when the expected Jewish Messiah appears he will exhibit some of the traits Christians already find in Jesus. ${ }^{15}$ If this is indeed the case then Phan believes we can posit two distinctive paths to an understanding of human salvation. The first is through the Christological symbols associated with Jesus; the second (here Phan is speaking in the context of the Christian-Jewish dialogue) through the religious symbols of Judaism, including that of the Jewish Messiah. But I believe Phan would be open to expanding this second set of symbols beyond the parameters of Judaism to the religions of Asia. Here is yet another example of how developments flowing from chapter four of Nostra Aetate may open important doors for the wider interreligious dialogue.

I would join Phan in suggesting that this perspective from the ChristianJewish dialogue establishes the possibility that specific Christological symbols associated historically with the Christian tradition may not be the only way of expressing the salvific reality that became apparent through the ministry and person of Jesus. How the varied symbols for expressing this reality might eventually coalesce is something beyond our current comprehension. Salvific reality is one; but the symbolic expression of that reality may be varied. This, it seems to me and to Phan as well, is a possibility introduced into the dialogical encounter by this passage from the Pontifical Biblical Commission's document. It may be something that the Pontifical Biblical Commission will need to pursue further since the Pontifical Biblical Commission does not have a mandate to do theological reflection.

\section{Turn to the Spirit in Interreligious Dialogue}

To bring these brief reflections to a close I would refer to a presentation I made in May 2016 at an international conference hosted by the theological faculty of the Catholic University of Leuven (KU Leuven) that focused on the Holy Spirit, Hermeneutics and Dialogue. ${ }^{16}$ That paper stressed the importance of a Spirit Christology in which Christ and the Spirit are fully integrated, may provide a better starting point within Christianity than other Christologies for developing a theology of religious pluralism. Developing a Spirit Christology may in fact be a task that the Asian church in particular take up as the dominant religions in Asia are ones in which some notion of spirit plays a central role. But even in the Chris-

\footnotetext{
${ }^{14}$ Peter Phan, "Jesus as Universal Savior,” 134-135.

${ }^{15}$ Pontifical Biblical Commission, "The Jewish People and Their Sacred Scripture in the Christian Bible," (Vatican City: Liberia Editrice Vaticana, 2002). For a discussion of the document, including my own reflections, cf. the special issue of The Bible Today (May/June 2003).

${ }^{16}$ The papers from this conference will be published by Peeters Publishing in Leuven.
} 
tian-Jewish dialogue an emphasis on the spirit, a notion certainly present in Judaism as Michael Lodahl argued some years ago, ${ }^{17}$ may bring us somewhat beyond the wall that Christology by itself has erected between the two faith communities. Thus building a Christian theology of religious pluralism upon a Spirit Christology rather than on Christology alone may in the end prove a sturdier bridge towards interreligious reconciliation and collaboration.

One other topic relevant for any discussion of the "uniqueness" of ChristianJewish relations and Nostra Aetate emerges from a proper understanding of the forces that helped generate the final text. It is often said, somewhat inaccurately, that the first three chapters of Nostra Aetate resulted pressure from bishops living in Muslim majority societies who feared the writing of a document devoted solely to Christian-Jewish relations could endanger their minority congregations. There is some truth to this perspective. Certainly the original impulse for the document was the result of the historic meeting between the French Jewish historian Jules Isaac who lost most of his family in the Shoah. In that meeting Professor Isaac urged Pope John XXIII to have the forthcoming Council take up the issue of antisemitism and its damaging consequences over the centuries, including during the Nazi era. But as John Borelli has shown as a result of his extensive collaboration with Thomas Stransky, C.S.P., the secretary of the drafting commission during the Council, that there were influential groups of bishops and experts who had been involved with a positive re-evaluation of Islam along the lines of the French Catholic scholar Louis Massignon. In the end, they proved an important force in expanding the document beyond the borders of the Christian-Jewish relationship. So the inclusion of material about Islam in the text, as well as in a less developed way material on other Asian religions, was dues to positive energy on the wider interreligious context at the Council and not merely fear of repercussion in the Muslim world. Knowing this history prevents us in my view from isolating the Christian-Jewish encounter from the other interreligious encounters the church maintains.

Over the years Christology has continued to be a major stumbling block for Christian-Jewish relations. But it also poses difficulties for the other interreligious dialogues in which Christians are engaged. This is particularly the case with regard to Islam, which claims some links both with Judaism and Christianity and their sacred texts, but also posits a revelatory claim beyond that of the two prior traditions. This claim is especially troubling for the Christian churches given their traditional proclamation of revelatory finality in and through Jesus the Christ.

As one who has struggled with this theological dilemma in a number of my writings over several decades I have come to recognize that as Christians we will never deepen and expand the foundations of our theology of interreligious dialogue, whether with the Jews or any other religious community, until we begin to develop a theological perspective which transforms our understanding of the Christ Event in a way that does not automatically reduce Jews and members of all

\footnotetext{
${ }^{17}$ Michael E. Lodahl, "Shekhinah/Spirit: Divine Presence in Jewish and Christian Religion," (Mahwah, NJ: Paulist Press), 1992.
} 
other religious traditions to a fundamentally inferior status. Is there a way Christians can maintain a belief in the universal meaning of the Christ Event while recognizing distinctive contributions within Jewish revelatory experiences. An international study group supported by Cardinal Walter Kasper, who at the time headed the Holy See's Commission for Interreligious Relations with the Jews, identified this as the "mega question" for Christian-Jewish relations today. ${ }^{18}$ But this "meta-question" also extends to all other interreligious dialogues in which the churches are currently engaged.

In my address at KU-Leuven I presented a tentative exploration of whether a move to an emphasis on Spirit Christology might enhance the emergence of a theology of religious pluralism on the part of Christianity. The key, in my perspective, would be a much greater emphasis on the presence and power of the Spirit in any effort by Christians to construct a viable theology of religious pluralism, a theology that might find a greater hearing among people of other faith communities who might otherwise still see a "pure" Christology as an unbridgeable stumbling block but who have some sense of the Spirit in their religious selfperception.

Spirit Christology has been a part of the theological scene in Christianity for many centuries. Mention has already been made of Michael Lodahl's volume on the theme of Spirit in Judaism. His volume, which received scant attention when it appeared in 1992 deserves a second look even though one rabbinic colleague in the Catholic-Jewish dialogue in Chicago Rabbi Yehiel Popuko of the Jewish Federation has argued that Lodahl presents a much too "activist" view of "Shekhinah" in Judaism. Popuko claims that the term in Judaism is merely presence unlike the "active" Spirit of the Christian tradition. But even if Popuko is correct, and this requires further exploration in Jewish source material, there is at least some connection between Christian and Jewish understandings of Spirit at the level of "presence."

In recent years we have seen something of a renaissance not merely in Spirit Christology approaches that remain deeply rooted in Chalcedon and Trinitarian theologies, but others as well which go beyond this more classical version of Spirit Christology. Such theologies propose a Christological outlook in which the Spirit replaces Christ Jesus as the principal Christological focal point. Theologians espousing such a perspective see their form of Spirit Christology superceding earlier versions of this approach generally known as Logos Christology. These theologians regard the emphasis on the Spirit in Christology as considerably more palatable to modern religious consciousness, as well as to interreligious dialogue, than a stress on the Incarnate Son. ${ }^{19}$ However, this approach has been criticized. Baptist theologian Greg Liston regards the effort by the above theologians to replace Logos Christology with their version of Spirit Christology as a "return" to

\footnotetext{
${ }^{18}$ Philip A. Cunningham and others, eds., Christ Jesus and the Jewish People Today: New Explorations of Theological Interrelationships, (Grand Rapids, MI: William B. Eerdmans, 2011).

${ }^{19}$ Ralph Del Colle, Roger Haight, D. Lyle Dabney and Greg Liston are theologians who have written on this theme in recent years.
} 
some very early Christological perspectives, giving this modern version the name of Spirit-Ebionism. He writes:

In attempting to replace the category of Logos with the category of Spirit in the person of Jesus this stream of researchers essentially replicates the errors of the early church in its initial Spirit Christological explorations. Openly rejecting the Chalcedonian and Nicene formulations, they invite the same critique and suffer from the same flaws as their early Church counterparts. To fully understand Jesus' identity, neither the Spirit nor the Son can be denied or neglected. ${ }^{20}$

At this point I will refrain from any discussion of his critique of the theologians who have advocated a turn to Spirit Christology in recent years. My initial assessment is that his critique does not do their perspectives total justice. Despite this critique Liston expresses some openness towards a "Spirit Christology." It would be a Spirit Christology in which the Trinitarian understanding of the Godhead is thoroughly integrated into Christological expression. But the integration cannot be such that it in any way obscures the reality of Jesus Christ as truly the Son of God.

I have some sympathy for Liston's critique, as well as his approach to Spirit Christology. Nonetheless I also harbor some reservations. Yes, I do believe that in any authentic form of Spirit Christology the bodily dimension of the Incarnation must remain front and center. But, as I see it, this bodily dimension is ultimately dependent on the Spirit's "anointing" of the Jewish man Jesus, which the New Testament refers to as "conceived of the Holy Spirit" (Mt 1:20); (cf. Lk 1:35 "the Holy Spirit will come upon [Mary]"). Without this anointing he remains a Jewish preacher of the first century; with this anointing he becomes Jesus the Incarnated Christ. While Liston rightly calls for an integration of Christ and the Spirit, in my judgement he keeps them in somewhat separate boxes.

By turning to the analysis offered by Lodahl in the volume already mentioned we may be able to move the discussion to a new constructive phase, one that can also prove useful in any consideration of a Christian theology of interreligious encounter. For out of a context of the Christian-Jewish relationship he puts forth a vision which preserves Jesus' concrete humanism while interpreting the presence of the Spirit in the man Jesus in a way that might open some links with religious perspectives beyond the parameters of Christianity.

Lodahl strongly emphasizes at the outset of his book that he is not presenting a vision of Trinitarian theology, or put another way, an exposition of the third person of the Trinity. Rather his is an effort to comprehend God's relatedness with all of creation. His own words go as follows. Spirit Christology is "a way of

\footnotetext{
${ }^{20}$ Greg Liston, “A ‘Chalcedonian' Spirit Christology,” Irish Theological Quarterly, 18:1 (February 2016): 74-93.
} 
talking about God 'as near' or in an active relation to creation, and especially to humanity." 21

Throughout his book Lodahl strongly emphasizes the profound connection between the Jewish man Jesus and the Spirit. But his approach is not primarily metaphysical such as a path through the Johannine LOGOS but through the witness of Jesus during his public ministry. The Spirit, fully imbedded in the physicality of Jesus, enabled him to express the dynamic presence of God within humanity. For Lodahl every encounter with Jesus and the Spirit is ultimately, and primarily, a direct encounter with God. In this regard, Lodahl is close to the thinking of the late Paul van Buren. Van Buren, who authored three volumes on the Christian-Jewish relationship, ${ }^{22}$ argued that what Christians have experienced through Jesus and his ministry is greater transparency regarding the profound integration of the divine presence within humanity and all of creation. Van Buren appeared to imply that this enhanced transparency was a unique dimension of the Christian vision, although this claim was primarily presented in discussions of the Christian Scholars Group and never published. He was to have produced a fourth volume detailing how the Christian-Jewish dialogue impacts wider interreligious understanding. However, that book took a different turn in the end as he returned in some ways to his earlier Barthian roots and soon thereafter died of cancer. But I have come to identify with van Buren's emphasis on transparency, particularly if it is tied to Lodahl's insistence on the Spirit at work in the ministry of Jesus.

The issue that remains for discussion is whether that transparency remains totally unique to Jesus or perhaps might be grasped through some other religious lens even if only partially. This issue is key for any discussion of the Spirit in terms of a Catholic theology of religious pluralism. If the answer is in the affirmative, then Spirit Christology may indeed open new doors for the church's vision of other religious communities. If we focus on the Christological dynamic present in Jesus and manifested in his ministry rather than primarily, or even exclusively. On the metaphysical dimensions of Christology we may be able to move towards a greater spiritual solidarity with people in other religious traditions, a solidarity that will also manifest itself in the socio-political sphere.

\section{Jewish Context of Jesus' Teachings}

As I bring these reflections on section two of G\&C to a close, a focus on two additional issues raised in that section would provide useful. The first relates directly to the just concluded discussion on Spirit Christology as the methodological center for interreligious dialogue, including Christian-Jewish relations. It concerns the positive impact of Judaism on Jesus' own self-identity as well as his teachings. The second involves the proper interpretation of the passages in Hebrews where the original covenant is contrasted with the "new" covenant

${ }^{21}$ Michael E. Lodahl, Shekhinah/Spirit, 3.

${ }^{22}$ Cf. Paul van Buren, Discerning the Way (NY: Seabury, 1980); A Christian Theology of the Jewish People, (NY: Seabury, 1983); and A Theology of the Jewish-Christian Reality: Christ in Context (San Francisco, CA: Harper \& Row, 1988). 
in a way that appears to render the original covenant totally obsolete after the Christ Event (cf. 8:7; 8:13; 9:15; 12:24; 13:20).

As for the first issue, G\&C deserves commendation for its strong emphasis on the Jewish context of Jesus' teachings and the importance of understanding this Jewish milieu for any authentic exegesis of these teachings. But then the document falls into fairly traditional language about Jesus being a "stumbling block" for Jews without in any way suggesting that our new focus on the profound links between Jesus and Judaism may require some reconsideration of how we describe the "divine" side of Jesus. His Jewishness, in my judgement, does carry implications for his divine side as well as his humanness. But G\&C fails to take up this question. It also seems oblivious to the fact that at least a few important Jewish scholars such as Daniel Boyarin, Elliot Wolfson, and Shaul Magid have turned their attention to the appearance of "incarnation" in the Judaism of Jesus' day. Boyarin even refers to Christology as a "job description" already present in Judaism and applied to rather than created for Jesus. ${ }^{23}$ There is hardly a groundswell of support for such research within contemporary Jewish religious scholarship. But neither does the wall with regard to Christology between Jews and Christians seem as hopelessly impenetrable as has been the case for centuries. Several Christian theologians, myself included, have tried to penetrate that wall. The December Vatican document is content to let the wall stand as is despite its call for continued theological reflection.

\section{The Letter to the Hebrews: Its Continuing Challenge for Interreligious Dialogue}

The second issue, the passages in Hebrews, are treated by the authors of G\&C in a constructive way that seems to reflect acquaintance on the part of the document's authors with the new scholarship on Hebrews by scholars such as the Swedish exegete Jesper Svartvik. ${ }^{24}$ The document rightly asserts the limited scope of this New Testament text. It is not meant to pronounce on the overall theology of the Church's Relationship with Judaism but rather was intended to support the still fragile faith of Jewish Christians. Because of this limited context, Hebrews was not utilized in the creation of the text of Nostra Aetate. This is contrary to the assertions of Cardinal Avery Dulles on the occasion of the celebration of Nostra Aetate's fortieth anniversary in 2005 that its omission from Nostra Aetate makes

\footnotetext{
${ }^{23}$ Cf. Daniel Boyarin, The Jewish Gospels: The Story of the Jewish Christ. (NY: The New Press, 2012); Elliot Wolfson, "Gazing Beneath the Veil: Apocalyptic Envisioning the End," in John Pawlikowski and Hayim G. Perelmuter, eds., Reinterpreting Revelation and Tradition: Jews and Christians in Conversation, (Franklin, WI: Sheed \& Ward, 1997), 77-103; and Sahul Magid, Hasidism Incarnate: Hasidism, Christianity and the Construction of Modern Judaism, (Palo Alto, CA: Stanford University Press, 2015).

${ }^{24}$ Jesper Svartvik, "Stumbling Block or Stepping Stone? On the Reception History of Hebrews 8:13," in Gabriella Gelardini and Harold W. Attridge, eds., Hebrews in Context, (Leiden: Brill, 2016), 316324.
} 
any proclamation of the continued validity of the Jewish covenant after the coming of Christ somewhat problematical. ${ }^{25}$

Overall, $\mathrm{G} \& \mathrm{C}$ does encapsulate many of the positive developments brought about by Nostra Aetate's chapter four. And its call further theological discussion is certainly welcome. Unfortunately, despite this call for further reflection, it continues to use an old framework rather than think outside the box and adopts a theological rigidity regarding a single covenant that will not stand the test in current interreligious scholarship.

${ }^{25}$ Cardinal Avery Dulles, S.J., "Evangelization and the Jews," with a response by Mary C. Boys, Philip A. Cunningham and John T. Pawlikowski, America 187:12 (October 21, 2002): 8-16; and "The Covenant with Israel," First Things (November 2005). 